\title{
JEJAK KESINAMBUNGAN MADRASAH DINIYAH MUAWANATUL MUSLIMIN SEJAK 1915 HINGGA 2012 DI KUDUS: STUDI SEJARAH
}

\author{
Moh. Rosyid \\ Dosen Sekolah Tinggi Agama Islam (STAIN) Kudus \\ Mrosyid72@yahoo.co.id
}

\begin{abstract}
This research focuses on the existence of a non formal Islamic educational institution - Muawanatul Muslimin - run by the community in Kudus Regency, Central Java since 1915. Characteristics of the school are: founded and managed by the kyai; specific subjects; distinctive dress patterns; learning time adjusted to the conditions of students; qualified to continue formal bigher education; male students only; flexible financial management; respect for educators; boliday on Friday; and simple learning tool. Constraints faced by madrasa are: afternoon learning time; government policies; no diploma certificates qualified for the formal employment; the proliferation of the number of madrasa diniyah in Kudus; extracurricular and additional bours in formal educational institutions. The last two were prioritized by students in formal educational institutions.
\end{abstract}

Keywords: Istiqomah, Madrasah Diniyah Muawanatul Muslimin, Kudus

\begin{abstract}
Abstrak
Penelitian ini memfokuskan pada keberadaan dan eksistensi pendidikan keagamaan Islam, diniyah nonformal -Muawanatul Muslimin-yang dikelola masyarakat di Kabupaten Kudus, Jawa Tengab sejak tabun 1915 bingga kini. Ciri khas yang dimiliki oleb madrasab tersebut, adalab; didirikan dan dikelola oleb para kyai; mata pelajaran dan pola berpakaian khas; waktu pembelajaran menyesuaikan kondisi peserta didik; berijazah yang dapat dijadikan syarat untuk melanjutkan pendidikan ke jenjang yang lebih tinggi; peserta didik atau santri laki-laki saja; manajemen keuangan yang lentur; penghormatan terhadap jerih payah bagi pendidik; libur pada hari Jumat; sarana pembelajaran sangat sederhana. Sementara kendala yang sering dibadapi pengelola berupa: waktu pembelajaran siang hari; kebijakan pemerintah tercurab pada
\end{abstract}


lembaga pendidikan formal; alumni tidak mendapatkan ijazah untuk dunia kerja formal; menjamurnya jumlah madrasah diniyah di Kudus; pembelajaran ekstrakulikuler pada sore hari; adanya jam tambahan di lembaga pendidikan formal.

Kata Kunci: Istiqomah, Madrasah Diniyah Muawanatul Muslimin, di Kudus

\section{Pendahuluan}

Alinia ketiga Pembukaan UUD 1945 menandaskan "untuk membentuk suatu pemerintahan negara Republik Indonesia yang melindungi segenap bangsa Indonesia dan seluruh tumpah darah Indonesia dan untuk memajukan kesejahteraan umum, mencerdaskan kehidupan bangsa". Kata 'cerdas' merupakan istilah yang terakomodasi dalam UU Nomor 20 Tahun 2003 Pasal 3 Pendidikan Nasional berfungsi mengembangkan kemampuan dan membentuk watak serta peradaban bangsa yang bermartabat dalam rangka mencerdaskan kehidupan bangsa. Menurut Howard Gardner (dalam Taufiq, 2003:17), terdapat sepuluh jenis kecerdasan manusia yakni; (1) kecerdasan bidang bahasa; (2) kecerdasan bidang matematika; (3) kecerdasan bidang spasial; (4) kecerdasan kinestetis; (5) kecerdasan bidang music; (6) kecerdasan komunikasi antarpribadi (people smart); (7) kecerdasan komunikasi pribadi (selfsmart); (8) kecerdasan naturalis; (9) kecerdasan eksistensial; dan (10) kecerdasan spiritual.

Dalam konteks lembaga pendidikan keagamaan point kesepuluh; kecerdasan spiritual mendapat perhatian ekstra di Madrasah Diniyah Muawanatul Muslimin, karena dengan kecerdasan spiritual, kecerdasan yang sembilan lainnya dapat lebih mudah dikembangkan bagi peserta didik karena telah diberi fondasi nilainilai keagamaan. Hal tersebut diperkokoh dalam perubahan keempat naskah UUD 1945 Bab XIII Pasal 31 (1) setiap warga negara berhak mendapatkan pendidikan, (2) setiap warga negara wajib mengikuti pendidikan dasar dan pemerintah wajib membiayainya. Warga negara pun dilibatkan dalam pelaksanaan pendidikan, tertuang dalam UU Nomor 20 Tahun 2003 Pasal 8 masyarakat berhak berperan serta dalam perencanaan, pelaksanaan, pengawasan, dan 
evaluasi program pendidikan. Pasal 9 masyarakat berkewajiban memberikan dukungan sumber daya dalam penyelenggaraan pendidikan. Warga negara berhak mendapatkan pendidikan agama dan/atau pendidikan keagamaan.

PP 55 Tahun 2007 tentang Pendidikan Agama dan Pendidikan Keagamaan Pasal 9 (1) Pendidikan keagamaan meliputi pendidikan keagamaan Islam, Kristen, Katolik, Hindu, Buddha, dan Khonghucu. Di sisi lain, pemerintah mengakomodasi kemandirian pendidikan keagamaan sebagaimana Pasal 12 (2) Pemerintah melindungi kemandirian dan kekhasan pendidikan keagamaan selama tidak bertentangan dengan tujuan pendidikan nasional. Dengan demikian, keberadaan pendidikan agama dan keagamaan berposisi sejajar dengan pendidikan umum (nonagama).

Pendidikan keagamaan dalam jalur pendidikan nonformal merupakan permasalahan yang perlu dikaji karena keberadaan jalur pendidikan formal perlu ditambah/didukung dengan pendidikan nonformal (PNF). PNF selama ini lebih didominasi menjadi wilayah kepedulian masyarakat. Realitanya, pemerintah sebagai penanggung jawab pendidikan nasional lebih memprioritaskan pendidikan formal daripada pendidikan nonformal. Hal ini sebagai bentuk kurangnya kepedulian pemerintah terhadap pendidikan nonformal, terutama pendidikan nonformal bidang agama dan keagamaan, meskipun esensi pendidikan tidak dibedakan atas keyakinan dan agama, formal atau nonformal, tetapi kebutuhan dasar demi meningkatkan kualitas hidup warga negara, diselenggarakan secara demokratis dan berkeadilan, tidak diskriminatif dengan menjunjung tinggi nilai hak asasi manusia (HAM), nilai keagamaan, kultural, dan kemajemukan bangsa.

Pada tataran realitas, peran masyarakat mendominasi pelaksanaan pendidikan nonformal bidang agama atau keagamaan, tidak bedanya pendidikan formal bidang agama. Data Kementerian Agama, Direktorat Jenderal Pendidikan Islam tahun 2012, dari 67 ribu madrasah, baik madrasah ibtidaiyah (MI), madrasah tsanawiyah (MTs), maupun madrasah aliyah (MA) sekitar 91 persen didirikan dan dikelola oleh swasta. Madrasah menampung sekitar 20 persen dari total siswa di Indonesia. Dari 67 ribu madrasah tersebut di atas, baru 68 persen yang terakreditasi dan guru madrasah baru sekitar 
57 persen yang mengikuti sertifikasi. Sebagai perbandingan, sekolah yang dikelola Kemendikbud sebanyak 130.563 SD negeri dan 12.689 SD swasta, 12.152 SMP swasta, 5.034 SMA negeri, dan 6.002 SMA swasta (Kompas, 4 Oktober 2012, hlm.12). Bahkan masyarakat di Kabupaten Kudus, Jawa Tengah sejak tahun 1915 mendirikan Madrasah Diniyah Muawanatul Muslimin (MDMM) yang eksis hingga kini. MDMM pendiriannya dimotori K.H. Abdullah Sajad bertujuan membekali ilmu pengetahuan agama bagi warga Kudus yang keberadaannya tidak lepas dari tantangan. Meskipun demikian, Madrasah Diniyah Muawanatul Muslimin tetap eksis di Kelurahan Kauman, Kecamatan Kota, Kabupaten Kudus sejak tahun 1915 hingga kini (tahun 2012).

Permasalahan dalam penelitian ini; Bagaimana dinamika Madrasah Diniyah Muawanatul Muslimin sejak tahun 1915 hingga 2012 di Kota Kudus? Kendala apakah yang dihadapi Madrasah Diniyah Muawanatul Muslimin? Serta solusi apakah yang dilakukan stakeholders Madrasah Diniyah Muawanatul Muslimin agar tetap istiqomah di tengah persaingan?

Tujuan yang diharapkan dengan naskah ini adalah memberi semangat pada pengelola lembaga pendidikan/madrasah untuk menyadari dan tergugah bahwa tahun 1915 sudah ada keberanian mendirikan madrasah, di tengah kekuasaan Belanda yang mencurigai lembaga pendidikan yang berbendera Islam. Apalagi era kini, yang mana fasilitas dan kemudahan mendirikan lembaga pendidikan diberi jalan lapang oleh pemerintah.

\section{Tinjauan Pendidikan Madrasah Diniyah}

Para peneliti yang menelaah pada pendidikan diniyah; Pertama, Abdul Aziz al-Bone (2006) Pendidikan Keagamaan Madrasah Diniyah Al Fatab (Studi tentang Respon Masyarakat terhadap Formalisasi Madrasah Diniyah di Kab. Demak, Jateng. Hasil penelitiannya menandaskan, berdasarkan pandangan Kurdi Mukhsin, seorang tokoh masyarakat Demak terhadap formalisasi Madrasah Diniyah, dan yang tergabung dalam lembaga Muhammadiyah dan Al-Ma'arif NU, dan MUI mereka setuju (positif) dengan adanya formalisasi Madrasah Diniyah karena selama ini terjadi 
dikotomi antara pendidikan umum dengan Madrasah Diniyah yang merugikan masyarakat, seperti ditolaknya Calon Kades hanya karena berijazah Madrasah Diniyah. Dengan diformalkannya Madrasah Diniyah, maka status alumninya terangkat. Adanya formalisasi Madrasah Diniyah, sarana prasarana dan guru akan membaik karena difasilitasi pemerintah. Tetapi, menurut akademisi pendidikan, dengan formalisasi pendidikan Madrasah Diniyah yang terjadi adalah menghilangkan spesifikasi dan melemahkan kemandirian masyarakat dalam pengelolaan Madrasah Diniyah. Dengan demikian, terdapat pendapat yang pro dan contra terhadap formalisasi Madrasah Diniyah Al-Fattah, Demak.

Kedua, Sunhaji (2006) Aplikasi Manajemen Pendidikan Berbasis Masyarakat di Madrasah Diniyah Al-Ittihad Pasir Kidul, Purwokerto Barat, Jateng. Partisipasi masyarakat Pasir Kidul mendukung pendanaan untuk pembangunan dan sarana prasarana serta berpartisipasi di bidang kurikulum.

Ketiga, Abdul Aziz al-Bone (2007) Studi Kompetensi Guru Madrasab Diniyah Ula di Kab. Agam, Sumbar. Hasil penelitian tersebut mendeskripsikan; Pertama, kompetensi profesionalisme berupa kewenangan, pengetahuan, dan kemampuan. Dari 20 guru Madrasah Diniyah Ula di Agam yang menjadi sampel penelitian menunjukkan bahwa, 60 persen (12 guru) berkemampuan profesional sangat baik, dan 40 persen (8 guru) kemampuan profesionalnya baik; Kedua, kompetensi paedagogik dalam pengetahuan dan penguasaan metode mengajar, mengelola kelas, menggunakan media belajar, penguasaan landasan pendidikan, dan mengelola interaksi belajar-mengajar dan menilai prestasi siswa, 60 persen kategori cukup, 15 persennya baik, 15 persen kurang baik, dan 10 persen sangat baik; Ketiga, kompetensi individual berupa pemilikan wewenang, pengetahuan dan sikap guru sebagai pribadi yang mantap dan perlu ditiru, 85 persen (17 guru) kompetensi individualnya baik, 10 persennya (2 guru) kompetensinya sangat baik, dan 5 persennya (1 guru) kompetensinya cukup; dan keempat, kompetensi sosial berupa hubungan dengan siswa, kasek, sesama guru, tata usaha, keluarga dan masyarakat, 55 persen (11 orang) cukup, 40 persen ( 8 orang) kompetensinya baik, dan 5 persen (1 orang) kompetensinya sangat baik. 


\section{Pendekatan Sejarah}

Kajian bidang sejarah menyesuaikan dengan perkembangan ilmu pengetahuan dan teknologi. Menurut Pranoto, kategori ilmu sejarah terpilah atas sejarah sosial, sejarah politik, sejarah ekonomi, sejarah psikologi, sejarah demografi, sejarah budaya dan seni rakyat, sejarah agama, sejarah lisan, sejarah lokal, sejarah nasional, sejarah keluarga, sejarah etnis, sejarah perempuan, sejarah pendidikan, sejarah agraria, sejarah desa, sejarah kota, sejarah maritim, dan sejarah pemikiran (Pranoto, 2010). Menurut Gottschalk, metode sejarah adalah proses menguji dan menganalisa secara kritis rekaman dari masa lampau hingga kini. Dengan metode sejarah juga dapat merekonstruksi peristiwa masa lampau (1983:32).

Sementara menurut Sjamsuddin penelitian sejarah mengedepankan analisis sejarah berupa; (1) Eksternal, yakni analisis sejarah yang mengulas karakteristik penulisan, sumber penulisan, jenis penulisan, tujuan penulisan, memahami kaidah penulisan, dan tahap penelitian sejarah; (2) Internal, yakni, menganalisis fakta kesaksian (fact of testimony), andal (reliable), benar (veracity), sesungguhnya (real), dan sumber yang sesuai (concurring sources). Analisis historiografi dilakukan dengan penafsiran, penjelasan, dan penyajian. Penafsiran (interpretation) dengan mengelompokkan fakta (auffassung) dan diformulasikan (darstellung), ketiganya dilakukan kroscek data (Sjamsuddin, 2007:130); (3) Historiografi, yakni analisis dilakukan agar terpenuhi karakteristik/orientasi penulisan sejarah meliputi; (1) pengetahuan tentang kejadian masa lalu kaitannya dengan masa kini (sejarah tradisional); (2) pengetahuan masa lalu, dengan menyelidiki dan menganalisanya (sejarah rasional). Hal ini terpenuhi dengan diperolehnya sumber primer karena penulisan sejarah adalah kegiatan ilmiah, sehingga tahapan analisis meliputi deskripsi, narasi, dan analitik yang terpenuhi sebagai acuan kerja (frame of reference). Analisis sejarah mengulas karakteristik, sumber, jenis, tujuan, dan memahami kaidah penulisan, serta tahap penelitian sejarah (Sjamsuddin, 2007:130). Penelitian sejarah dengan langkah; (i) topiknya sesuai, peneliti mendalami ilmu sejarah; (ii) ada bukti yang relevan; (iii) mengkritisi dengan analisis sejarah; (iv) menyajikannya (Sjamsuddin, 2007:89). Keempat langkah tersebut tertuang dalam naskah ini. Obyek dan analisisnya menggunakan dua hal yang 
berlatar belakang gabungan keilmuan yakni sejarah dan ilmu sosial lainnya maka menggunakan analisis interkoneksitas dan obyek forma (pendekatan) sejarah.

Penulisan sejarah tersusun dalam cerita yang memiliki prinsip penceritaan. Juga memiliki langkah penulisan yang mengedepankan strategi penulisan. Mengulas sejarah bukan sesuatu yang nihil pesan untuk kehidupan. Sebagai ilmu, sejarah merekonstruksi peristiwa masa lampau dan mengedepankan aspek keaslian (otentisitas), keterpercayaan (kredibilitas), dan keterhandalan (reliabilitas) (Kuntowijoyo, 2001:199). Sejarawan membuat periodisasi peristiwa atau kejadian penting masa lalu dari obyek studi yang dikajinya. Penentuan ruang lingkup terbatas dalam studi sejarah diharapkan memudahkan penggalian data dan analisis data. Ruang lingkup kajian sejarah meliputi lingkup kajian ruang (space), waktu (time), dan keilmuan. Ruang lingkup ruang/tempat telaah di Kelurahan Kauman, Kecamatan Kota, Kabupaten Kudus, Jawa Tengah. Ruang lingkup waktu sejak berdiri tahun 1915 hingga 2012. Ruang lingkup keilmuan adalah ilmu bantu yang digunakan menganalisis penelitian adalah ilmu psikologi sosial yang menyangkut karakter masyarakat, ilmu sosiologi untuk memahami konstruksi sosial, ilmu antropologi untuk memahami budaya masyarakat Kudus, dan ilmu sosial lainnya yang mendukung untuk menganalisis penelitian ini.

\section{Metode Penelitian}

Penelitian ini menggunakan pendekatan historis yakni penelitian yang bertujuan mengulas historisitas Madrasah Diniyah Muawanatul Muslimin sejak tahun 1915 hingga tahun 2012. Pendekatan studi tersebut dimaksudkan menelaah eksistensi, kendala, dan solusi agar keberlangsungan lembaga pendidikan keagamaan nonformal berbentuk madrasah diniyah di Kabupaten Kudus yang ditopang sepenuhnya oleh masyarakat terpaparkan, sekaligus dapat dijadikan bahan informasi publik untuk mengikutinya. Studi kritis juga dilakukan untuk mengkritisi sejauhmana masyarakat Kudus yang diidentikkan sebagai kota/masyarakat santri mampu melaksanakan keberlangsungan madrasah diniyah nonformal secara utuh di tengah animo warga Kudus yang sekolah menghendaki ijazah formal, sebagaimana dipersyaratkan oleh industri di Kudus dalam merekrut tenaga kerja. 
Penentuan Latar dan lokasi penelitian ini adalah; (i) peneliti berdomisili di Kabupaten Kudus, diharapkan menggali dan menganalisis data diperoleh kemudahan mengakses; (ii) hasil dokumentasi penulis, belum banyak telaah yang mengulas pendidikan keagamaan Islam nonformal berbentuk diniyah. Selama ini oleh para peneliti lebih cenderung menelaah pendidikan agama Islam formal atau pendidikan keagamaan nonformal berupa pesantren; dan (iii) ketertarikan peneliti mengulas topik ini karena keberadaan diniyah Muawanatul Muslimin masih eksis sejak prakemerdekaan hingga era Reformasi, di tengah tidak sebandingnya perhatian pemerintah terhadap pendidikan diniyah, dibanding maksimalnya perhatian pemerintah terhadap pendidikan formal. Direktorat Pondok Pesantren dan Diniyah, Kementerian Agama, sebagai lembaga vertikal yang bertanggung jawab atas pelaksanaan pendidikan keagamaan Islam jalur nonformal dipandang belum maksimal meningkatkan kinerja madrasah diniyah nonformal, hanya lebih intens pada diniyah formal dalam aras kebijakan.

Dengan demikian, perlu untuk mengungkapkan faktor eksisnya Madrasah Diniyah Muawanatul Muslimin di Kabupaten Kudus dengan pendekatan historis difokuskan pada; (i) sejarah berdirinya; (ii) faktor eksistensi dan kendala keberadaan Madrasah Diniyah; dan (iii) solusi yang dilakukan pengelola dalam mengeksistensikan Madrasah Diniyah Muawanatul Muslimin dalam bentuk kebijakan riil.

Adapun sumber informan sekaligus menjadi subyek penelitian adalah pengelola Madrasah Diniyah, pengurus Yayasan, dan guruguru (asatidz) Muawanatul Muslimin. Pengumpulan data dalam penelitian ini terdiri observasi, wawancara, dokumentasi, dan gabungan ketiganya/triangulasi atau analisis antarkomponen bertujuan mengombinasikan dan memformulasikan seluruh teknik pengumpulan data secara padu.

\section{Analisis}

\section{Idealitas Pendidikan}

UU Nomor 20 Tahun 2003 Pasal 1 (1) pendidikan adalah usaha sadar dan terencana untuk mewujudkan suasana belajar 
dan proses pembelajaran agar peserta didik secara aktif mengembangkan potensi dirinya untuk memiliki kekuatan spiritual keagamaan, pengendalian diri, kepribadian, kecerdasan, akhlak mulia, serta keterampilan yang diperlukan dirinya, masyarakat, bangsa dan negara. Definisi tersebut menandaskan bahwa unsur yang dikembangkan bagi peserta didik di antaranya adalah kekuatan spiritual keagamaan, dengan harapan tujuan pendidikan tercapai. Sedangkan tujuan pendidikan termaktub jelas pada Pasal 3 dari Undangundang tersebut di atas yakni untuk berkembangnya potensi peserta didik agar menjadi manusia yang beriman dan bertakwa kepada Tuhan Yang Maha Esa, berakhlak mulia, sehat, berilmu, cakap, kreatif, mandiri, dan menjadi warga negara yang demokratis serta bertanggung jawab. Iman dan takwa merupakan tujuan utama dalam pembelajaran di Madrasah Diniyah Muawanatul Muslimin. Hal ini dibuktikan dengan muatan mata pelajaran yang disajikan dalam pembelajaran.

Pendidikan juga harus mampu melayani masyarakatnya atas aktivitas yang diperoleh bagi masyarakat (peserta didik) dari penyelenggara pendidikan dalam proses pembelajaran. Pelayanan ini terpetakan atas sarana prasarana, proses pembelajaran, hingga strategi keberhasilan pendidikan yang direngkuh oleh peserta didik dengan sukses yang difasilitasi oleh penyelenggara pendidikan, khususnya dewan guru. Standar pelayanan pendidikan yang ideal tertuang dalam PP Nomor 19 Tahun 2005 tentang standar nasional pendidikan yang terpetakan atas standar isi, standar mutu, standar pelaksanaan, dan standar lulusan. Keempat standar tersebut lebih terfokus pada pendidikan formal, adapun pendidikan di Madrasah Diniyah Muawanatul Muslimin masih dalam taraf sederhana yakni pembelajaran pesantren plus.

Jalur pendidikan nonformal (PNF) memiliki satuan kelompok belajar (Paket A, B, dan C, kelompok belajar, dan magang), kursus, kelompok bermain, penitipan anak, dan pendidikan sejenis lainnya. Jadi, PNF merupakan pendidikan yang diselenggarakan di luar sekolah formal (di luar ruang kelas reguler) yang terlembaga atau tidak terlembaga. Prinsip kegiatannya terbuka, tidak terikat, dan tidak terpusat atau dapat berupa lanjutan atau pengayaan dari berbagai program sekolah, pengembangan dari program sekolah, dan 
program yang setara dengan pendidikan sekolah.

Keleluasaan PNF jauh lebih besar dari pendidikan sekolah dengan kualifikasi; (a) dapat disesuaikan dengan kebutuhan masyarakat yang senantiasa berubah karena PNF tidak dapat diselenggarakan melalui jalur sekolah; (b) sebagai jembatan antara pendidikan sekolah dengan dunia kerja yang berkedudukan sebagai penambah, pelengkap, dan pengganti pendidikan formal; (c) tidak berjenjang dan tidak berkesinambungan; (d) yang terlembaga atau tidak terlembaga, mengutamakan latihan dan pembiasaan (babit formation); dan (e) berada di luar arena pendidikan (kelas). Adapun tujuan PNF adalah; (i) melayani warga belajar supaya tumbuh dan berkembang sedini mungkin dan sepanjang hayat untuk meningkatkan martabat dan mutu kehidupannya; (ii) membina warga belajar agar memiliki pengetahuan, keterampilan, dan sikap mental yang diperlukan untuk mengembangkan diri, bekerja mencari nafkah atau melanjutkan ke tingkat dan/atau jenjang pendidikan yang lebih tinggi; dan (iii) memenuhi kebutuhan belajar masyarakat yang tidak dapat dipenuhi dalam jalur pendidikan sekolah (Komar, 2006:218).

Penyelenggaraan PNF terdiri pemerintah, badan, kelompok atau perseorangan yang bertanggung jawab atas pelaksanaan pendidikan yang diselenggarakannya. Masyarakat dapat menyelenggarakan jenis pendidikan nonformal kecuali pendidikan kedinasan. Adapun satuan PNF dapat berupa padepokan pencak silat, sanggar kesenian, balai latihan, pondok pesantren, majlis taklim, kelompok pengajian, penataran, kursus reguler, dan bimbingan belajar di media massa. Bahkan dalam PP Nomor 55 Tahun 2007 kedudukan madrasah diniyah sebagai bentuk pendidikan keagamaan nonformal. Pendidikan Nonformal (PNF) adalah; (i) melayani warga belajar supaya tumbuh dan berkembang sedini mungkin dan sepanjang hayat untuk meningkatkan martabat dan mutu kehidupannya; (ii) membina warga belajar agar memiliki pengetahuan, keterampilan, dan sikap mental yang diperlukan untuk mengembangkan diri, bekerja mencari nafkah atau melanjutkan ke tingkat dan/atau jenjang pendidikan yang lebih tinggi; dan (iii) memenuhi kebutuhan belajar masyarakat yang tidak dapat dipenuhi dalam jalur pendidikan sekolah. Penyelenggara PNF terdiri pemerintah, 
badan, kelompok atau perseorangan yang bertanggung jawab atas pelaksanaan pendidikan yang diselenggarakannya. Masyarakat dapat menyelenggarakan jenis pendidikan nonformal kecuali pendidikan kedinasan. Adapun satuan PNF dapat berupa padepokan pencak silat, sanggar kesenian, balai latihan, pondok pesantren, majlis taklim, kelompok pengajian, penataran, kursus reguler, dan bimbingan belajar di media massa. Madrasah diniyah dalam naskah ini merupakan bentuk pendidikan keagamaan nonformal.

Terdapat lima terobosan yang dapat dimanfaatkan dalam pendidikan nonformal untuk memecahkan masalah mendesak, menurut Komar (2006:243) berupa pengentasan kemiskinan, mengatasi pengangguran, mengatasi penduduk usia sekolah, mengatasi putus sekolah (dropt out), dan peluang pengembangan pribadi. Dalam konteks pendidikan keagamaan diniyah lebih pada pengembangan pribadi yang agamis-islami.

Produk perundangan telah menggariskan bahwa pendidikan menjadi soko guru bangsa. Sebagaimana Amanat UUD 1945, UU Nomor 20 tahun 2003 tentang Sistem Pendidikan Nasional, PP Nomor 55 tahun 2007 tentang pendidikan agama dan keagamaan, dan PP Nomor 48 tahun 2008 tentang wajib belajar. Perundangan juga menegaskan bahwa negara bertangung jawab terhadap pelaksanaan pendidikan nasional dalam bidang pendanaan, manajemen kebijakan, dan pelayanan. Pemerintah pun memberi keleluasaan kepada masyarakat dalam mengelola lembaga pendidikan.

UU Nomor 20 Tahun 2003 Pasal 1 (16) pendidikan berbasis masyarakat adalah penyelenggaraan pendidikan berdasarkan kekhasan agama, sosial, budaya, aspirasi, dan potensi masyarakat sebagai perwujudan pendidikan dari, oleh, dan untuk masyarakat. Pasal 4 (1) Pendidikan diselenggarakan secara demokratis dan berkeadilan serta tidak diskriminatif dengan menjunjung tinggi HAM, nilai keagamaan, nilai kultural, dan kemajemukan bangsa. Pasal 12 (1) Setiap peserta didik pada setiap satuan pendidikan berhak (b) mendapatkan pelayanan pendidikan sesuai dengan bakat, minat, dan kemampuannya. Pembukaan UUD 1945 perubahan keempat Pasal 28 C (1) setiap orang berhak mengembangkan diri melalui pemenuhan kebutuhan dasar dan berhak mendapatkan pendidikan demi meningkatkan kualitas hidupnya dan Pasal 28 D (1) setiap 
orang berhak atas pengakuan, jaminan, perlindungan, dan kepastian hukum yang adil serta perlakuan yang sama di hadapan hukum. Konsekuensinya pemerintah harus menegakkan UU Nomor 20 Tahun 2003 Pasal 11 (2) Pemerintah dan Pemerintah Daerah wajib menjamin tersedianya dana guna terselenggaranya pendidikan bagi setiap warga negara yang berusia tujuh sampai dengan lima belas tahun. Pasal 34 (2) Pemerintah dan Pemerintah Daerah menjamin terselenggaranya wajib belajar minimal pada jenjang pendidikan dasar tanpa memungut biaya.

\section{Bentuk Pendidikan Keagamaan Islam antara Formal dan nonformal}

PP Nomor 55 Tahun 2005 Pasal 14 (1) Pendidikan keagamaan Islam berbentuk pendidikan diniyah dan pesantren, (2) Pendidikan diniyah sebagaimana dimaksud pada ayat (1) diselenggarakan pada jalur formal, nonformal, dan informal. Pendidikan diniyah formal, sebagaimana tertuang dalam Pasal 15 menyelenggarakan pendidikan ilmu-ilmu yang bersumber dari ajaran agama Islam pada jenjang pendidikan anak usia dini, pendidikan dasar, pendidikan menengah, dan pendidikan tinggi. Pasal 16 (1) Pendidikan diniyah dasar menyelenggarakan pendidikan dasar sederajat MI/SD yang terdiri enam tingkat dan pendidikan diniyah menengah pertama sederajat MTs/ SMP yang terdiri tiga tingkat. (2) Pendidikan diniyah menengah menyelenggarakan pendidikan diniyah menengah atas sederajat MA/SMA yang terdiri tiga tingkat. (3) Penamaan satuan pendidikan diniyah dasar dan menengah sebagaimana dimaksud pada ayat (1) dan ayat (2) merupakan hak penyelenggara pendidikan yang bersangkutan. Pasal 17 (1) Untuk dapat diterima sebagai peserta didik pendidikan diniyah dasar, seseorang harus berusia sekurangkurangnya 7 (tujuh) tahun. (2) Dalam hal daya tampung satuan pendidikan masih tersedia maka seseorang yang berusia enam tahun dapat diterima sebagai peserta didik pendidikan diniyah dasar. (3) Untuk dapat diterima sebagai peserta didik pendidikan diniyah menengah pertama, seseorang harus berijazah pendidikan diniyah dasar atau yang sederajat. (4) Untuk dapat diterima sebagai peserta didik pendidikan diniyah menengah atas, seseorang harus berijazah pendidikan diniyah menengah pertama atau yang sederajat. 
Pasal 18 (1) Kurikulum pendidikan diniyah dasar formal wajib memasukkan muatan pendidikan kewarganegaraan, bahasa Indonesia, matematika, dan ilmu pengetahuan alam dalam rangka pelaksanaan program wajib belajar. (2) Kurikulum pendidikan diniyah menengah formal wajib memasukkan muatan pendidikan kewarganegaraan, bahasa Indonesia, matematika, ilmu pengetahuan alam, serta seni dan budaya. Pasal 19 (1) Ujian nasional pendidikan diniyah dasar dan menengah diselenggarakan untuk menentukan standar pencapaian kompetensi peserta didik atas ilmu-ilmu yang bersumber dari ajaran Islam. (2) Ketentuan lebih lanjut tentang ujian nasional pendidikan diniyah dan standar kompetensi ilmu-ilmu yang bersumber dari ajaran Islam sebagaimana dimaksud pada ayat (1), ditetapkan dengan peraturan Menteri Agama dengan berpedoman kepada Standar Nasional Pendidikan. Pasal 20 (1) Pendidikan diniyah pada jenjang pendidikan tinggi dapat menyelenggarakan program akademik, vokasi, dan profesi berbentuk universitas, institut, atau sekolah tinggi. (2) Kerangka dasar dan struktur kurikulum pendidikan untuk setiap program studi pada perguruan tinggi keagamaan Islam selain menekankan pembelajaran ilmu agama, wajib memasukkan pendidikan kewarganegaraan dan bahasa Indonesia. (3) Mata kuliah dalam kurikulum program studi memiliki beban belajar yang dinyatakan dalam satuan kredit semester (sks). (4) Pendidikan diniyah jenjang pendidikan tinggi diselenggarakan sesuai dengan Standar Nasional Pendidikan.

Sementara pendidikan Diniyah nonformal tertuang dalam Pasal 21 (1) Pendidikan diniyah nonformal diselenggarakan dalam bentuk pengajian kitab, majelis taklim, pendidikan al-Quran, diniyah takmiliyah, atau bentuk lain yang sejenis, (2) Pendidikan diniyah nonformal sebagaimana dimaksud pada ayat (1) dapat berbentuk satuan pendidikan, dan (3) Pendidikan diniyah nonformal yang berkembang menjadi satuan pendidikan wajib mendapatkan izin dari kantor Departemen Agama Kabupaten/Kota setelah memenuhi ketentuan tentang persyaratan pendirian satuan pendidikan.

\section{Dinamika Madrasah Diniyah Muawanatul Muslimin sejak tabun 1915 bingga 2012}

Awal didirikannya Madrasah Diniyah Muawanatul Muslimin tahun 1915 oleh K.H. Abdullah Sajad, mertua dari Bapak K.H Arwani 
Amin (sesepuh masyarakat Kudus). Tujuan awal dari pendirian madrasah ini adalah harapan menolong warga muslim Kudus, agar terdidik dan mampu mensiarkan Islam dengan bekal pendidikan keagamaan. Bila kita lihat tahun berdirinya, tahun itu masa kolonial Belanda di Hindia Belanda (Nusantara). Sikap dan pandangan negatif Belanda terhadap lembaga pendidikan berbendera Islam bukan rahasia lagi. Meskipun demikian, Madrasah Diniyah Muawanatul Muslimin tetap berdiri hingga kini. Penamaan madrasah memberi sinyal bahwa berdirinya madrasah diniyah tersebut sebagai jembatan penolong (muawwanah) bagi calon siswa dan siswa agar tetap kokoh mengkaji ilmu agama. Hal ini sesuai dengan amanat PP 55 Tahun 2007 Pasal 14 (3) Penamaan satuan pendidikan diniyah dasar dan menengah merupakan hak penyelenggara pendidikan.

Dari tujuan dasar berdirinya madrasah yang memfasilitasi peserta didik untuk mendapatkan pengetahuan keislaman, di samping tersedianya pondok pesantren di lingkungan setempat. Hal ini sesuai dengan program pemerintah yang mengakomodasi kemandirian pendidikan keagamaan, yang tertuang dalam PP 55 Tahun 2007 Pasal 12 (2) Pemerintah melindungi kemandirian dan kekhasan pendidikan keagamaan selama tidak bertentangan dengan tujuan pendidikan nasional. Pasal 14 (1) Pendidikan keagamaan Islam berbentuk pendidikan diniyah dan pesantren, (2) Pendidikan diniyah sebagaimana dimaksud pada ayat (1) diselenggarakan pada jalur formal, nonformal, dan informal. Madrasah Diniyah dalam naskah ini diselenggarakan pada jalur nonformal.

Esensi pendidikan nonformal menurut Kamil (2009: 24) adalah sebagai modes of learning, memberikan akses pendidikan dan belajar yang lebih luas kepada warga belajar, sehingga berpeluang memiliki daya penyesuaian (adaptability), daya lentur (flexibility), kapasitas inovatif, dan entrepreneurial attitudes and aptitudes. Dengan demikian, warga belajar tertantang mencari dan memperkuat basic knowledge and competence, curiosity and motivations, critical and creative behaviour untuk menciptakan situasi yang memungkinkan dirinya lebih mapan.

Untuk membedakan dengan pondok pesantren, penyelenggara Madrasah Diniyah Muawanatul Muslimin memiliki pola yang 
berbeda sebagai kekhasan dalam hal:

Pertama, mata pelajaran meliputi al-Quran, Ilmu Hadis, Ilmu Tauhid, Ilmu Falak, Pasolatan, Imlak, Pegon, Ilmu Tafsir, Arut, Insak, Nahwu-Shorof, Ilmu Tajwid, dan Tarikh. Pemberian materi pembelajaran tersebut sealur dengan PP Nomor 55 Tahun 2007 Pasal 1 (1) pendidikan agama adalah pendidikan yang memberikan pengetahuan dan membentuk sikap, kepribadian, dan keterampilan peserta didik dalam mengamalkan ajaran agamanya, yang dilaksanakan sekurang-kurangnya melalui mata pelajaran. Pasal 2 (1) Pendidikan agama berfungsi membentuk manusia Indonesia yang beriman dan bertakwa kepada Tuhan Yang Maha Esa serta berakhlak mulia dan mampu menjaga kedamaian dan kerukunan hubungan intern dan antarumat beragama. (2) Pendidikan agama bertujuan untuk berkembangnya kemampuan peserta didik dalam memahami, menghayati, dan mengamalkan nilai-nilai agama yang menyerasikan penguasaannya dalam ilmu pengetahuan, teknologi, dan seni.

Kedua, pola berpakaian peserta didik dikenal pakaian santri pondok pesantren plus yakni berpakaian sebagaimana santri yakni berpeci/berkupyah dan bersarung. Peci dan sarung merupakan identitas pakaian khas laki-laki di lingkungan pesantren, sedangkan pakaian khas perempuan berupa jilbab.

Ketiga, waktu pembelajaran mulai pukul 15 s.d 17.00 WIB dengan pertimbangan para santri pada pagi hari sekolah formal dan di malam hari di pondok pesantren. PP 55 Tahun 2007 Pasal 25 (1) Diniyah takmiliyah bertujuan untuk melengkapi pendidikan agama Islam yang diperoleh di SD/MI, SMP/MTs, SMA/MA, SMK/ MAK atau di pendidikan tinggi dalam rangka peningkatan keimanan dan ketakwaan peserta didik kepada Allah SWT.

Keempat, mempertahankan corak khas berupa (1) guru yang mengajar juga sebagai ustad pengasuh pesantren (2) pesantren plus yakni alumninya berijazah yang dapat digunakan untuk melanjutkan jenjang pendidikan formal lebih tinggi.

Kelima, hanya memiliki santriwan karena Madrasah Diniyah khusus putri telah diselenggarakan di Madrasah Taswiruttullab Salafiyah Kudus (lokasinya bertetangga). 
Keenam, birokasi pendidikan agar tetap eksis dalam melaksanakan pendidikan, tidak terkesan tanpa kontrol, dan tidak ada anggapan tanpa kendali manajemen, maka bagi calon santri diwajibkan membayar uang gedung sebesar Rp 25 ribu, Sumbangan Pelaksanaan Pendidikan (SPP) atau syahriab setiap bulan Rp 10 s.d 15 ribu (berdasarkan kondisi perekonomian santri).

Ketujuh, mewujudkan penghormatan terhadap jerih payahnya sebagai wujud pengakuan kerja yang ikhlas dan ekspert di bidangnya, para guru mendapat honor/bisyaroh berdasarkan masa pengabdian. Guru ada yang mendapatkan honor Rp 25 ribu per bulan, ada pula Rp 50 ribu per bulan, dan tertinggi Rp 60 ribu per bulan per guru. Dana bersumber dari syahriah (iuran bulanan) peserta didik. Pada masa kepemimpinan Bupati Kudus, Musthofa, setiap guru mendapatkan uang tali asih tahunan dari Kabupaten tiap akhir Ramadan, semula per guru Rp 55 ribu, sedangkan pada tahun 2011 meningkat menjadi Rp 500 ribu.

Kedelapan, pelaksanaan pembelajaran pada hari Jumat dan bulan Ramadan diliburkan. Adapun pelaksanaan pendaftaran siswa baru setiap tanggal 15 Syawal.

Kesembilan, kondisi sarana pembelajaran sangat sederhana, bernuansa pesantren dan madrasah pola tradisional yakni hanya memiliki 2 lokal/kelas dengan sarana pembelajaran sederhana, belum disentuh metode dan media pembelajaran kekinian, seperti belum memiliki komputer. Hal ini sesuai dengan amanat PP 55 Tahun 2007 Pasal 25 (3) Penyelenggaraan diniyah takmiliyah dilaksanakan di masjid, mushalla, atau di tempat lain yang memenuhi syarat.

Kesepuluh, PP 55 Tahun 2007 Pasal 25 (2) Penyelenggaraan diniyah takmiliyah dapat dilaksanakan secara berjenjang atau tidak berjenjang. Pasal 21 (1) Pendidikan diniyah nonformal diselenggarakan dalam bentuk pengajian kitab, Majelis Taklim, Pendidikan Al Quran, Diniyah Takmiliyah, atau bentuk lain yang sejenis. Madrasah Diniyah yang dijadikan obyek penelitian ini dalam bentuk diniyah takmiliyah.

\section{Kendala Pendidikan Madrasab Diniyah Muawanatul Muslimin}

UU Nomor 20 Tahun 2003 Pasal 1 (16) pendidikan berbasis masyarakat adalah penyelenggaraan pendidikan berdasarkan ke- 
khasan agama, sosial, budaya, aspirasi, dan potensi masyarakat sebagai perwujudan pendidikan dari, oleh, dan untuk masyarakat. Pasal 4 (1) Pendidikan diselenggarakan secara demokratis dan berkeadilan serta tidak diskriminatif dengan menjunjung tinggi hak asasi manusia, nilai keagamaan, nilai kultural, dan kemajemukan bangsa. Pasal 12 (1) Setiap peserta didik pada setiap satuan pendidikan berhak (b) mendapatkan pelayanan pendidikan sesuai dengan bakat, minat, dan kemampuannya. Pembukaan UUD 1945 perubahan keempat Pasal 28C (1) setiap orang berhak mengembangkan diri melalui pemenuhan kebutuhan dasar dan berhak mendapatkan pendidikan demi meningkatkan kualitas hidupnya dan Pasal 28 D (1) setiap orang berhak atas pengakuan, jaminan, perlindungan, dan kepastian hukum yang adil serta perlakuan yang sama di hadapan hukum. Pendidikan berbasis masyarakat yang terdapat pada Madrasah Diniyah Muawanatul Muslimin adalah penyelenggaraan pendidikan berdasarkan kekhasan agama Islam, dengan corak budaya santri, dan mengoptimalkan potensi tokoh agama masyarakatnya.

Keberadaan Madrasah Diniyah Muawanatul Muslimin menghadapi tekanan dari berbagai aras, terutama adanya kebijakan pendidikan oleh pemerintah dan dinamika kehidupan masyarakat masa kini, berupa:

Pertama, waktu pembelajaran pada siang hari. Waktu tersebut merupakan waktu setelah peserta didik menghabiskan energinya pada pendidikan formal sehingga tenaga peserta didik tidak optimal karena telah terkuras pada pagi hari.

Kedua, kebijakan pemerintah yang mengucurkan dana pada lembaga pendidikan formal berupa dana biaya operasional sekolah/ madrasah (BOS/BOM) sehingga peserta didik dibebaskan dari biaya pendidikan, pendidik disejahterakan dalam program sertifikasi guru, beasiswa bagi peserta didik (beasiswa prestasi maupun beasiswa miskin), beasiswa bagi guru untuk studi lanjut, dan lainnya. Tetapi pendidikan diniyah (keagamaan nonformal) belum mendapat sentuhan perhatian serupa bagi peserta didik dan pendidiknya. Konsekuensinya beban biaya pelaksanaan pendidikan menjadi tanggungan sepenuhnya penyelenggara pendidikan. 
Ketiga, harapan wali peserta didik bahwa menyekolahkan anak identik dengan kepemilikan keterampilan untuk meraih lapangan kerja berbekal ijazah pada pendidikan formal. Harapan ini tumbang karena pendidikan nonformal tidak menjanjikannya ijazah yang dibutuhkan dunia kerja.

Keempat, semakin menjamurnya jumlah madrasah diniyah di wilayah Kudus. Hal ini secara langsung atau tidak langsung menjadi pesaing dalam proses penerimaan siswa (santri) baru.

Kelima, aktivitas pembelajaran ekstrakulikuler pada sore hari oleh peserta didik yang berada di sekolah/madrasah formal, peserta didik tersebut juga menjadi santri di Madrasah Muawanatul Muslimin, sehingga bagi siswa yang melaksanakan ekstarkulikuler secara otomatis tidak masuk kelas di Madrasah Diniyah karena waktu pembelajaran ekstrakulikuler pada waktu proses pembelajaran Madrasah Diniyah dilaksanakan.

Keenam, bagi peserta didik Madrasah Diniyah yang juga belajar di sekolah/madrasah formal, khususnya yang berada di kelas akhir, pada lembaga pendidikan formal mentradisikan adanya jam tambahan, kursus, atau lainnya untuk mempersiapkan ujian nasional. Tradisi tersebut bersamaan dengan waktu pembelajaran di Madrasah Diniyah, sehingga peserta didik sering meninggalkan pembelajaran di Madrasah Diniyah.

Keenam tekanan tersebut dalam kondisi masif, akan tetapi kesadaran penyelenggara pendidikan, guru, orangtua murid, dan murid tetap kokoh karena kinerjanya bermodalkan amal ibadah dalam bentuk pengembangan ilmu agama untuk perjuangan agama Islam dan mendalami ajaran Islam.

\section{Solusi Stakeholders Madrasah Diniyah Muawanatul Muslimin agar Istiqomah di tengah Persaingan}

Menghadapi kendala dalam kinerjanya Madrasah Diniyah Muawanatul Muslimin, dalam menjalankan perannya melalui tindakan dalam bentuk solusi antara lain:

Pertama, dewan guru berasal dari tokoh agama (ulama) yang juga ustadz pesantren yang ada di Kudus. Keberadaan ustadz pada madrasah menurut Daulay (2001:59) merupakan unsur pokok yakni 
pimpinan/pengelola, guru/ustadz, siswa, perangkat keras, perangkat lunak, dan pengajaran mata pelajaran agama Islam. Hal ini merupakan bentuk respon positif yang diangankan wali murid bahwa para kyai yang juga menjadi guru di madrasah diniyah diharapkan putra-putranya mendapatkan keberkahan ilmu dalam proses pembelajaran.

Kedua, lokasi madrasah tidak dipindah meskipun dalam kondisi sederhana karena menghormati dan mengenang jejak awal berdirinya madrasah, sekaligus dengan dekatnya Madrasah diniyah dengan Pondok pesantren untuk mempermudah santri menjadi peserta didik. Pondok pesantren Kudus berdasarkan hasil riset LSM Cermin Kudus tahun 1998 sebanyak 89 ponpes. Adapun ponpes di Kudus yang berada di sekitar Madrasah Diniyah Muawanatul Muslimin adalah (a) Pondok pesantren Yambaul Quran (didirikan oleh K.H Arwani (alm), sekarang dilanjutkan oleh putranya Gus Ulin Nuha dan Ulil Albab, di Bale Tengahan, (b) Taswiquttullab Salafiyah (TBS) didirikan oleh K.H Ma'mun Ahmad, di Bale Tengahan, (c) Al-Irsyad, didirikan K.H.Ma'ruf, (d) Ma'abid oleh Ustadz Tamrin di Kajeksan, (e) Mazroatul Ulum, pendiri Kyai Maksum sekarang diasuh oleh Ustad Nur Muttaqin di Damaran, (f) Ma'had Ulumus Syariab Yanbaul Quran (Musyiq) oleh Ustad Arifin Fanani, di Wanaran, (g) Takhdzibul Akblaq, pendiri Kyai Abu Amar (alm), sekarang diasuh oleh ustadz Arifin, di Wijilan, Purwosari, (h) Darul Furqon, Kyai Abdul Qodir, di Kalugawen Janggalan, (i) Raudlotul Muta'alimin, pendirinya Kyai Irsyad (alm) selanjutnya diampu oleh ustad Ma'ruf Irsyad (alm), di Langgar Dalem, (j) Darul Falah Raudlotul Mardliyyah, pendirinya Kyai Hisyam, sekarang diasuh oleh Gus Munir, di Janggalan.

Ketiga, tingkatan pendidikan mengikuti dinamika kekinian, meliputi tingkat 'Ula (tingkat dasar), wustho (tingkat menengah), dan jenjang 'Ulya. Peserta didik yang menyelesaikan studi mendapatkan ijazah dan dapat digunakan untuk melanjutkan pendidikan formal jenjang yang lebih tinggi.

Keempat, mempertahankan kekhasan mata pelajaran, yang mana mata pelajaran tersebut sudah tidak lagi dijadikan materi pembelajaran di sekolah/madrasah formal, seperti ilmu falak, praktik salat (fasolatan), imlak, pegon, arut, dan insak. 
Kelima, mempertahankan kekhasan dalam berbusana yakni mengenakan sarung, peci, dan tidak bersepatu dalam proses pembelajaran antara pendidik dan peserta didik.

Keenam, pada bulan Ramadan, madrasah libur sebulan penuh. Hal ini memberi kesempatan pada para murid untuk mengaji/ mendalami kitab yang khusus dikaji pada bulan Ramadan (pasanan) di pesantren sekitar Madrasah Diniyah.

Ketujuh, kelonggaran bagi peserta didik yang bila membayar syahriyah (SPP) tidak tepat waktu. Hal ini dilakukan dengan pertimbangan karena peserta didik lazimnya lebih mengutamakan pembayaran SPP pada jenjang pendidikan formal dan peserta didik banyak yang berasal dari keluarga nonkaya.

Kedelapan, pelaksanaan pembelajaran setiap hari masuk kelas pukul 15 s.d 17.00 WIB setiap hari Sabtu s.d Kamis. Waktu tersebut dipertahankan dengan pertimbangan, pada pukul 07.00 WIB s.d 14.00 WIB peserta didik belajar di bangku pendidikan formal dan pada malam hari mengaji di pondok pesantren di sekitar Madrasah Diniyah.

Kesembilan, mengokohkan pada hati pendidik oleh pengelola lembaga pendidikan madrasah, bahkan menjadi jati diri pendidik (ustad) sebagai insan yang benar-benar berjuang mensiarkan Islam melalui dunia pendidikan madrasah, bukan orientasi kesejahteraan secara materi. Hal ini sesuai dengan kelahiran lembaga pendidikan Islam telah tumbuh seiring dengan penyebaran Islam, menurut Syukur berdirinya madrasah sangat terkait dengan proses dakwah islamiyah (2004:19).

Kesepuluh, hari Jumat sebagai hari libur agar peserta didik dapat berekreasi/istirahat, sebagaimana hari libur bagi santri dan lembaga pendidikan formal bernuansa keislaman di Kudus. Bagi penyelenggara pendidikan formal di Kudus, libur di hari Jumat karena memegang prinsip bahwa hari Jumat adalah hari yang mulia, peserta didik dapat melaksanakan aktivitas di rumah masing-masing sekaligus mempersiapkan Shalat Jumat dan mentradisikan ziarah kubur di pagi hari. 


\section{Kesimpulan}

Dalam perjalanannya Madrasah Diniyah Muawanatul Muslimin sejak tahun 1915 hingga 2012 di Kota Kudus melalui dinamika yang dinamis dengan karakter:

1. Mata pelajaran meliputi al-Quran, hadis, tauhid, falak, fasolatan, imlak, pegon, tafsir, arut, insak, nahwu-shorof, tajwid, dan tarikh. Pelajaran tersebut sebagai ciri khas sejak berdiri hingga kini dengan memberikan pengetahuan dan membentuk sikap, kepribadian, dan keterampilan peserta didik dalam mengamalkan ajaran agamanya dan berfungsi membentuk manusia Indonesia yang beriman dan bertakwa kepada Tuhan Yang Maha Esa serta berakhlak mulia dan mampu menjaga kedamaian dan kerukunan hubungan intern dan antarumat beragama. Pendidikan Madrasah Diniyah tersebut bertujuan untuk berkembangnya kemampuan peserta didik dalam memahami, menghayati, dan mengamalkan nilai-nilai agama. Peserta didik Madrasah Diniyah Muawanatul Muslimin dikhususkan bagi laki-laki (santriwan) sementara peserta didik perempuan (sntriwati) telah diselenggarakan di Madrasah Taswiruttullab Salafiyah Kudus. Pola berpakaian santri ponpes plus yakni berpakaian sebagaimana santri (berpeci dan bersarung) juga berseragam. Sementara waktu pembelajaran mulai pukul 15 s.d 17.00 WIB dengan pertimbangan para santri pada pagi hari sekolah formal dan di malam hari di ponpes. Mempertahankan corak khas berupa (1) guru yang mengajar juga sebagai ustad pengasuh pesantren (2) pesantren plus yakni alumninya berijazah yang dapat digunakan untuk melanjutkan jenjang pendidikan formal lebih tinggi.

2. Pada ranah birokasi pendidikan, lembaga ini menekankan pada eksistensi dalam melaksanakan pendidikan yang tidak terkesan tanpa kontrol dan tanpa kendali manajemen, maka bagi calon santri diwajibkan membayar uang gedung sebesar Rp 25 ribu, SPP Rp 10 s.d 15 ribu (berdasarkan kondisi perekonomian santri). Serta mewujudkan penghormatan terhadap jerih payahnya sebagai wujud pengakuan kerja yang ikhlas, para guru mendapat honor/bisyaroh guru/ustad berdasarkan masa pengabdian. Guru 
ada yang mendapatkan honor Rp 25 ribu per bulan, ada pula Rp 50 ribu per bulan, dan tertinggi Rp 60 ribu per bulan per guru. Dana bersumber dari syahriah (iuran bulanan) peserta didik. Hal ini terlihat dari kondisi sarana pembelajaran sangat sederhana, bernuansa pesantren dan madrasah yakni hanya memiliki 2 lokal/kelas dengan sarana pembelajaran sederhana, belum disentuh metode dan media pembelajaran kekinian. Madrasah Diniyah yang dijadikan obyek penelitian ini dalam bentuk diniyah takmiliyah.

3. Kendala yang dihadapi Madrasah Diniyah Muawanatul Muslimin berupa (1) waktu pembelajaran pada waktu siang hari setelah peserta didik melaksanakan pendidikan formal. (2) kebijakan pemerintah yang mengucurkan dana pada lembaga pendidikan formal berupa dana $\mathrm{BOS} / \mathrm{BOM}$, pendidik disejahterakan dalam program sertifikasi guru, beasiswa bagi peserta didik (beasiswa prestasi maupun beasiswa miskin), beasiswa bagi guru untuk studi lanjut, dan lainnya. (3) alumni madrasah tidak mendapat ijazah untuk meraih lapangan kerja formal. (4) madrasah diniyah di wilayah Kudus berdiri di setiap desa menjadi pesaing dalam penerimaan siswa baru. (5) ekstrakulikuler pada sore hari oleh peserta didik yang berada di sekolah/madrasah formal, bagi peserta didik yang menjadi santri di Madrasah Muawanatul Muslimin, secara otomatis tidak masuk kelas di Madrasah Diniyah. (6) bagi peserta didik di Madrasah Diniyah yang juga belajar di sekolah/madrasah formal pada kelas akhir, tertradisi adanya jam tambahan, kursus, atau lainnya untuk mempersiapkan ujian nasional, sehingga peserta didik sering meninggalkan pembelajaran di Madrasah Diniyah. Keenam tekanan tersebut tertepis oleh kesadaran secara kolektif antara penyelenggara pendidikan, guru, orangtua murid, dan murid yang tetap kokoh karena kinerjanya bermodalkan amal dengan ilmu agama untuk perjuangan agama Islam dan mendalami ajaran Islam.

4. Solusi yang dilakukan stakeholders Madrasah Diniyah Muawanatul Muslimin agar tetap istiqomah di tengah persaingan dengan cara; (1) dewan guru berasal dari tokoh agama (ulama) yang juga ustad pesantren di Kudus. Hal ini sesuai harapan peserta 
didik dan wali murid untuk menimba ilmu dengan kyai; (2) lokasi madrasah tetap sejak berdiri karena menghormati dan mengenang jejak awal berdirinya madrasah, sekaligus dengan dekatnya Madrasah Diniyah dengan Ponpes di lingkungan Madrasah Diniyah untuk mempermudah santri menjadi peserta didik; (3) tingkatan pendidikan mengikuti dinamika kekinian, meliputi tingkat 'Ula (tingkat dasar), wustho (tingkat menengah), dan jenjang 'Ulya. Pelaksanaan pembelajaran setiap hari masuk kelas pukul 14 s.d 17.00 WIB setiap hari Sabtu s.d Kamis. Peserta didik yang menyelesaikan studi mendapatkan ijazah dan dapat digunakan untuk melanjutkan pendidikan formal jenjang yang lebih tinggi; (4) mempertahankan kekhasan mata pelajaran, seperti Ilmu Falak, praktik salat (Pasolatan), Imlak, Pegon, Arut, dan Insak; (5) mempertahankan kekhasan dalam berbusana yakni mengenakan sarung, peci, dan tidak bersepatu dalam proses pembelajaran antara pendidik dan peserta didik; (6) pada bulan Ramadan, kegiatan pendidikan dan pengajaran Madrasah diliburkan sebulan penuh agar para murid dapat mengaji/mendalami kitab yang khusus dikaji pada bulan Ramadan (pasanan) di pesantren sekitar Madrasah Diniyah; (7) kelonggaran membayar syahriyah (SPP) tidak tepat waktu; (8) pembelajaran pukul 15 s.d 17.00 WIB setiap hari Sabtu s.d Kamis, pertimbangan, pada pukul 07.00 WIB s.d 14.00 WIB peserta didik belajar di bangku pendidikan formal dan pada malam hari mengaji di pondok pesantren; dan (9) Pengelola yayasan mengokohkan hati pendidik madrasah sebagai pendakwah.

\section{Daftar Pustaka}

Al-Bone, Abdul Aziz. 2006. Pendidikan Keagamaan Madrasah Diniyah Al-Fatah: Studi tentang Respon Masyarakat terhadap Formalisasi Madrasah Diniyah di Kab.Demak, Jateng. Jurnal Edukasi Puslitbang Pendidikan Agama dan Keagamaan Balitbang dan Diklat Depag. Vol.4 No.4: Jakarta. 2007. Studi Kompetensi Guru Madrasah Diniyah Ula di Kab.Agam, Sumbar. Jurnal Edukasi Puslitbang Pendidikan Agama dan Keagamaan Balitbang dan Diklat Depag. Vol.5 No.4: Jakarta. 
Daulay, Haidar Putra. 2001. Historisitas dan Eksistensi Pesantren, Sekolah, dan Madrasah. Tiara Wacana: Yogyakarta.

Gottschalk, Louis. 1983. Mengerti Sejarah, (terjemahan Nugroho Notosusanto. Jakarta: Universitas Indonesia Press.

Kamil, Mustofa. 2009. Pendidikan Nonformal. Alfabeta: Bandung. Kuntowijoyo. 2001. Pengantar Ilmu Sejarah. Bentang: Yogyakarta. Pasiak, Taufiq. 2003. Revolusi IQ/EQ/SQ Antara Neurosains dan Al-Quran. Mizan:Bandung.

Pranoto, Suhartono W. 2010. Teori dan Metodologi Sejarah. Graha Ilmu : Jakarta.

Sjamsuddin, Helius. 2007. Metodologi Sejarah, edisi ke-2. Yogyakarta:Ombak.

Sugiyono.2006. Metode Penelitian Pendidikan Pendekatan Kuantitatif, Kualitatif, dan Research and Development. Alfabeta: Bandung.

Sunhaji. 2006. Aplikasi Manajemen Pendidikan Berbasis Masyarakat di Madrasah Diniyah Al-Ittihad Pasir Kidul, Purwokerto Barat, Jateng. Jurnal Penelitian Agama STAIN Purwokerto, Vol.7 No.1.

Syukur, Fatah. 2004. Dinamika Madrasah dalam Masyarakat Industri. Pusat Kajian Pengembangan Ilmu Keislaman: Semarang.

\section{Perundang-Undangan}

Peraturan Pemerintah RI Nomor 55 Tahun 2007 tentang Pendidikan Agama dan Pendidikan Keagamaan.

Peraturan Pemerintah RI Nomor 47 Tahun 2008 tentang Wajib Belajar.

Undang-Undang Nomor 20 Tahun 2003 tentang Sistem Pendidikan Nasional 